\title{
ROLA KOŚCIOŁA W EUROPEJSKIM KRYZYSIE POKOJU WEDŁUG JOSEPHA RATZINGERA
}

Czym jest pokój i co stanowi jego podstawę? Odpowiedź na to pytanie wydaje się prosta: pokój to brak wojny. Ta definicja ma jednak znaczenie negatywne, gdyż oznacza istnienie określonego stanu jako brak innego stanu, którym jest wojna. Jest to związane z łacińskim słowem pax, w którym zawarta jest idea wzajemnej relacji opartej na świadomie przyjętej umowie. Zatem jeśli pokój to brak przemocy, to czy ta przemoc dotyczy jedynie ciała czy również sumienia i przekonań? W tej sytuacji należałoby stwierdzić, że pokój to nie tylko brak wojny, lecz również brak zagrożenia. ${ }^{1}$

Czy dzisiejsza Europa jest jedynie ideą, czy jako siła moralna po II wojnie światowej stanowi siłę pojednania między narodami oraz siłę w ustanawianiu i tworzeniu pokoju? „Europa jako idea polityczna musi (...) zastąpić model państwa narodowego szerszą koncepcją wspólnoty kulturowej (...). Bo nie bycie przeciwko sobie, lecz jedynie bycie ze sobą tworzy również pojedyncze narody". ${ }^{2} \mathrm{Z}$ drugiej zaś strony Europa „ukazuje się jako roszczenie do władzy i przemoc gospodarcza inkasująca to, co inne, to znaczy umniejszająca lub wręcz niszcząca własne prawa i własną formę życia innych". ${ }^{3}$ Mimo negatywnych doświadczeń Europy z nacjonalizmem, jakie miała ona na początku ubiegłego wieku, to właśnie on stanowi, według Josepha Ratzingera, jedno z podstawowych zagrożeń dla pokoju. Kardynał

1 Zob. J.J. P a w li k, Światopoglądowe uwarunkowania koncepcji pokoju, w: W. L i z a k, A.M. S ol or z (red.), Z problematyki pokoju w stosunkach międzynarodowych, Warszawa 2014, s. 79-91.

2 J. R a t z ing e r, Czas przemian w Europie. Miejsce Kościoła i świata, Kraków 2005, s. 105.

Tamże, s. 108. 
mówi w tym przypadku o dwóch wymiarach nacjonalizmu. Pierwszy to wywyższenie własnego narodu na podstawie świętości, a więc tworzenie swojego rodzaju mitu własnego narodu z wykorzystaniem religii. Miało to już miejsce w historii, gdy Trzecia Rzesza usiłowała stworzyć własny „rodzaj chrześcijaństwa”. ${ }^{4}$ Wielu z nas przychodzi w tym momencie myśl dotycząca radykalizmu islamskiego, który, opierając się na założeniach religijnych, właśnie w ten sposób mitologizuje i stawia swój naród ponad innymi. Drugi wymiar współczesnego nacjonalizmu polega na połączeniu go $\mathrm{z}$ wiarą $\mathrm{w}$ postęp i z obietnicą powstania nowej ludzkości istniejącej dla siebie, bez odwołania do wartości transcendentnych. ${ }^{5}$ Człowiek musi znać sens swojego życia, mieć wartości. Według Ratzingera „istnieją wartości, które są warte tego, że się dla nich umiera, bo życie okupione ich zdradą opiera się na zdradzie samych podstaw życia i stąd jest od wewnątrz zniszczone. (...) Dotyczy to nie tylko jednostek; również i kraju, wspólna kultura posiada wartości, które uzasadniają zaangażowanie życia; gdy zabraknie takich wartości, znikają również podstawy i siły społecznej spoistości, dzięki którym kraj trwa jako wspólnota życia". ${ }^{6}$ Zakwestionowanie świata istniejącego po śmierci prowadzi człowieka do żądzy życia, ekstazy i spełnienia, co powoduje spadek wartości życia. Kiedy mi się ono nie podoba, to mogę je odrzucić. Kiedy nie podoba mi się moje życie, popełniam samobójstwo lub poddaję się eutanazji. Gdy nie podoba mi się życie innego człowieka, zabijam go lub dokonuję aktu terroru. Człowiek potrzebuje etosu, który wymaga wiary w stworzenie i nieśmiertelność i powoduje świadomość wzięcia na siebie odpowiedzialności za życie swoje i innych. ${ }^{7}$

4 O trzech zasadniczych postaciach chrześcijaństwa: rzymskiej, germańskiej i bizantyjsko-słowiańskiej zob. A. v o n $\mathrm{H}$ a r n a c k, Das Wesen des Christentums, Stuttgart 1950, s. 113-117.

Zob. J. R a t z i n g e r, Czas przemian w Europie, s. 113.

6 Tamìe, s. 33.

7 Zob. tamíe: s. 34. 
Kardynał Ratzinger mówi o kolejnych czterech zagrożeniach dla pokoju. Pierwszym jest wojna ogólnoludzka, w której użyta broń zniszczyłaby ludzkość. Druga to wojna klasyczna, czyli taka, która jest prowadzona $\mathrm{w}$ różnych częściach świata od wielu lat. Trzecie zagrożenie dotyczy utrzymania wewnętrznego pokoju w państwie, w którym ze względu na poczucie niesprawiedliwości pojawiają się liczne tzw. ruchy wyzwolenia. Według nich „państwo nie chroni już prawa, lecz podaje za prawo to, co jest samowolą". ${ }^{8}$ Można na tę sytuację spojrzeć również z innej strony, mianowicie w ten sposób, ,że ideologiczne ugrupowania tworzą sobie partyjną ideę prawa i w ten sposób wyłamują się ze wspólnoty prawa dla osiągnięcia własnych celów". ' Zarówno w jednym, jak i drugim przypadku mamy do czynienia ze złym rozumieniem pojęć „,prawo” i „bezprawie”, terroryzm zaś podaje się za ruch wyzwolenia, tak jak to jest w przypadku Trzeciego Świata, co jest często popierane przez państwa europejskie. Zagrożenie czwarte to nic innego jak panowanie przemocy we wnętrzu państwa, które jest wynikiem dojścia do władzy grupy budującej „,pokój” na swój sposób. Mamy tu do czynienia z państwem totalitarnym doskonałym w swojej tyranii. „Zewnętrznie panuje tu pokój, ale jest to pokój cmentarza". ${ }^{10}$ Wszystkie te grupy mają swój sposób walki o pokój, ale zapominają o tym, że ,prawda o człowieku wymaga, by ta walka była prowadzona za pomocą środków odpowiadających ludzkiej godności. To dlatego systematyczne i świadome uciekanie się do ślepej przemocy przez którąkolwiek ze stron musi być potępione. Ten, kto ufa w przemoc i sądzi, że dzięki temu zapanuje większa sprawiedliwość, pada ofiarą śmiertelnej iluzji. Przemoc zrodzi przemoc i zdegraduje człowieka. Urąga ona godności ludzkiej w osobie poszkodowanych i poniża też godność tych, którzy się posługują przemocą". ${ }^{11}$

\footnotetext{
8 Tamże, s. 38.

9 Tamże, s. 39.

10 Tamże, s. 41.

${ }^{11}$ Libertatis nuntius, XI, 7, http://www.kns.gower.pl/stolica/nuntius.htm\#38 (dostęp: 14 II 2016).
} 
Każde państwo buduje swoje prawa, które w innym państwie mogą okazać się bezprawiem. Dlatego też obok ustaleń prawnych państwa, obok wszechpanującego pieniądza na pierwsze miejsce wysuwają się prawa człowieka, o których czytamy w Powszechnej Deklaracji Praw Człowieka: „Wszyscy ludzie rodzą się wolni i równi pod względem swej godności i swych praw. Są oni obdarzeni rozumem i sumieniem i powinni postępować wobec innych w duchu braterstwa". ${ }^{12}$ Należy pamiętać o godności ludzkiej, która jako wartość jest uprzednia w stosunku do prawa państwowego, gdyż ona istnieje własną mocą jako wartość wyższego porządku, którą każdy ma obowiązek szanować. Owa godność, a także wolność oraz równość i solidarność są podstawowymi czynnikami dla istnienia państwa prawa i demokracji, co warunkuje pokój w obrębie danego państwa. ${ }^{13}$ Kościół broni podstawowych praw człowieka, zwłaszcza poszanowania życia i wolności religijnej. Ci, którzy mają władzę polityczną, nie mogą naruszać praw innych ludzi. ${ }^{14}$ Niestety, kardynał mówi, że „dzisiaj mamy do czynienia z nowym rodzajem moralizmu, którego słowami kluczowymi są sprawiedliwość, pokój i zachowywanie idei stworzenia. Są to pojęcia, istotne wartości moralne, którym powinniśmy koniecznie dawać wyraz. Ale ten rodzaj moralizmu pozostaje niejasny i wślizguje się prawie nieuchronnie w sferę polityki i do różnych partii"'15 (tłum. A.P.-K.). Joseph Ratzinger zaznacza, że prawo jest formowane

12 Zob. więcej: Powszechna Deklaracja Praw Człowieka, http://www.unesco.pl/ fileadmin/user_upload/pdf/Powszechna_Deklaracja_Praw_Czlowieka.pdf (dostęp: 16 III 2016).

13 Zob. B. G a c k a, Znaczenie osoby w teologii Josepha Ratzingera - Benedykta XVI, Warszawa 2010, s. 263-264.

14 Zob. Osoba ludzka sercem pokoju, Orędzie Ojca Świętego Benedykta XVI na Światowy Dzień Pokoju 1 stycznia 2007 roku, http://www.opoka.org.pl/biblioteka/W/ WP/benedykt_xvi/przemowienia/pokoj2007_08122006.html (dostęp: 16 III 2016).

15 „Es gibt heute einen neuen Moralismus, dessen Schlüsselwörter Gerechtigkeit, Friede und Bewahrung der Schöpfung sind. Das sind Begriffe, die wesentliche moralische Werte, die wir alle notwendig haben, zum Ausdruck bringen. Aber dieser Moralismus bleibt vage und schlittert damit fast unausweichlich in die Sphäre der Politik und der Parteien"; Rede am Vorabend des Todes von Johannes Paul II. anlässlich der Verleihung des „Preises des Heiligen Benedikt für die Förderung 
przez człowieka, ale musi ono być uzasadnione w transcendencji. „Gdzie Bóg i ustanowiona przezeń podstawowa forma ludzkiej egzystencji zostaje wyrugowana i odsunięta w obszar prywatny, czysto subiektywny, zanika pojęcie prawa, a wraz z nim również fundament pokoju" ${ }^{16}$ Wyznacznikiem życia dla człowieka powinna być boska rzeczywistość. Jeśli jej nie ma, nie ma też wiary, która prowadzi do wzajemnego szacunku i miłości między ludźmi, a gdy jej nie ma, do głosu dochodzi zło, które jest przyczyną egoizmu, przemocy, braku zaufania oraz nieposzanowania godności ludzkiej, skutkiem czego jest brak pokoju. Joseph Ratzinger zaznacza wyraźnie, że jeśli Bóg straci znaczenie, to nie będzie pokoju na świecie. ${ }^{17}$

I tu nasuwa się pytanie o wpływ Kościoła na budowanie pokoju w świecie, pytanie o to, co chrześcijanin może uczynić w tej kwestii, a do czego nie ma prawa. Kościół ma prawo wychowywać człowieka, obudzić w nim wrażliwość na prawdę, dlatego że zmysł prawdy jest zagłuszany często przez zmysł władzy i użyteczności, która sama w sobie nie jest niczym złym, lecz staje się złem, kiedy przestaje zwracać uwagę na prawdę. Człowiek musi uwrażliwić się na Boga, a przez to czuć siłę sumienia, by dzięki niemu tworzyć dobre prawo w społeczeństwie. ${ }^{18}$ Kościół nie może wymusić pokoju, ale ma zdolność podtrzymywania ludzi w powołaniu do miłości, dzięki której może dawać siłę przeżycia na terenach wojennych, jak też służyć ludziom biednym, chorym i cierpiącym fizycznie oraz duchowo. W instrukcji Libertatis conscientia czytamy, że pasterze nie powinni bezpośrednio ingerować w strukturę polityczną państwa ani w organizację życia społecznego. To powinni robić świeccy, Kościół zaś ma głosić królestwo Chrystusowe, by wszyscy zostali zbawieni. ${ }^{19}$

des Lebens und der Familie in Europa“ http://www.heise.de/tp/artikel/20/20742/1. html (dostęp: 7 II 2016).

16 J. R a t z i n g e r, Czas przemian w Europie, s. 47.

17 Te n ż e, Szukajcie tego, co w górze, tłum. M. R o t k i e w i c z, Kraków 2007, s. 124 .

18 Zob. te n ż e, Czas przemian w Europie, s. 48.

19 Więcej na ten temat zob. http://www.kns.gower.pl/stolica/conscientia.htm (dostęp: 14 III 2016). 
Kardynał wyznacza chrześcijanom zadania, dzięki którym będzie można zachować pokój w świecie. Przede wszystkim należy podkreślać znaczenie zła, nie ignorować go i nie traktować z przymrużeniem oka, jak zwykło się ostatnio robić. Mówienie o diable i jego działaniu w świecie stało się na początku nowego tysiąclecia swoistym opowiadaniem bajek, które nawiązują do poprzedniego wieku, wskazując na jego zabobonny charakter. Diabła nie ma, piekła nie ma, a więc Boga też nie ma, gdyż o nim opowiadały nam jedynie nasze babcie, które nie miały takiego dostępu do wiedzy i techniki jak my. Nie miały takich możliwości rozwoju, jakie daje współczesna Europa, a co za tym idzie, potrzebowały siły sprawczej, czyli Boga. Niestety, właśnie w taki sposób myśli w większości współczesna cywilizacja. Dlatego kolejnym zadaniem chrześcijanina jest akceptowanie hierarchii wartości oraz przeciwdziałanie zapominaniu o Bogu i tworzeniu z Niego postaci mitycznej. Kościół powinien również wychowywać ludzi do zachowania pokoju, a więc wskazywać wartości przeciwstawiające się wojnie i przemocy, z których najważniejsza jest miłość względem bliźniego. ${ }^{20}$ „Ludzkość potrzebuje głębokiej odnowy kulturowej, musi odkryć na nowo wartości stanowiące solidny fundament, na którym można zbudować lepszą przyszłość dla wszystkich". ${ }^{21}$

Kościół musi być sobą i brać na siebie odpowiedzialność za społeczeństwo, „musi być gotowy na cierpienie, przygotowywać miejsce dla boskości nie przez moc, lecz przez ducha, nie przez siłę instytucjonalną, lecz przez świadectwo, przez miłość, życie i cierpienie, i w ten sposób pomagać społeczeństwu odnaleźć jego moralną tożsamość". ${ }^{22}$ Aby zrozumieć pojęcie pokoju, należy również zwrócić uwagę na słowa Jezusa: „Pokój zostawiam wam, pokój mój daję wam. Nie

20 J. R a t z i n g e r, Szukajcie tego, co w górze, s. 125.

${ }_{21}$ Jeśli chcesz krzewić pokój, strzeż dzieła stworzenia, Orędzie Ojca Świętego Benedykta XVI na Światowy Dzień Pokoju 1 stycznia 2010 roku, https://w2.vatican. $\mathrm{va} /$ content/benedict-xvi/pl/messages/peace/documents/hf_ben-xvi_mes_20091208_ xliii-world-day-peace.html (dostęp: 10 II 2016).

22 J. R a t z i n g e r, Czas przemian w Europie, s. 160. 
tak jak daje świat, Ja wam daję" (J 14, 27). ${ }^{23}$ Kardynał Ratzinger zaznacza, że oba logiony należy rozpatrywać łącznie, chociaż nadrzędny sens wypowiedzi jest taki, że to Chrystus przynosi pokój. Nie można go jednak pojmować w sposób banalny i odrzucać od siebie prawdy. Kościół, tak samo jak każdy rząd, nie może unikać konfliktów dla tzw. świętego spokoju, lecz ma obowiązek głosić prawdę, a nawet wieść spór, by prawda osiągnęła swój cel. Pozorny pokój rodzi konflikty i obłudę, a, niestety, chęć dotarcia lub głoszenia prawdy często wiąże się z cierpieniem. „Albowiem pierwszym obowiązkiem obywatela i chrześcijanina nie jest spokój, lecz odniesienie do wielkiego daru, który zawdzięczamy Chrystusowi i który może się stać cierpieniem, który może się stać walką, aż po męczeństwo i właśnie w ten sposób ustanawia pokój” ${ }^{24}$ Kościół to ludzie, którzy jeśli przyjmują naukę Chrystusa, powinni dążyć do prawdy, przez co również do pokoju, zaczynając od siebie. I w ten właśnie sposób może powstać społeczność, która uniesie kryzys wiary wynikający przede wszystkim z rozprzestrzeniającego się laicyzmu, gdyż brak wiary staje się brakiem pokoju. Działanie Kościoła widoczne jest w projektach misyjnych i wielu dziełach miłosierdzia, ale najważniejszym miejscem Kościoła jest liturgia, gdyż to ona prowadzi nas do Boga, a Boga wprowadza w nasz świat. ${ }^{25}$

Zadaniem Kościoła jest przekraczanie granic a nie przeobrażanie się w Kościół narodowy. Kościół katolicki należy do wszystkich kultur, epok, należy do całego świata. Joseph Ratzinger mówi, że „idziemy coraz bardziej w kierunku chrześcijaństwa z wyboru, zdecydowanego. (...) Powiedziałbym, że dzisiaj trzeba z jednej strony wzmacniać, ożywiać i rozszerzać zdecydowanie to chrześcijaństwo, aby więcej ludzi wyznawało świadomie swoją wiarę i żyło

23 P. S e e w a ld, Bóg i świat. Wiara i życie w dzisiejszych czasach, z kardynałem Josephem Ratzingerem rozmawia Peter Seewald, tłum. G. S o w i ń s k i, Kraków 2001, s. 205.

24 Tamże, s. 206.

25 Zob. Benedykt XVI w rozmowie z Peterem Seewaldem, Świattość świata. Papiez, Kościól i znaki czasu, Kraków 2011, s. 163. 
nią. Z drugiej strony musimy uznać, że chociaż jako chrześcijanie nie jesteśmy po prostu czymś tożsamym z kulturą czy narodem jako takim, to jednak mamy siłę, aby tworzyć i kształtować kulturowe oraz narodowe wartości, które są przyjmowane także wtedy, gdy większość społeczeństwa nie jest wierzącymi chrześcijanami”. ${ }^{26}$

W swoim przemówieniu w Asyżu w 2012 r. kardynał, już jako papież Benedykt XVI, zwrócił uwagę na pojęcie wolności, które nierozerwalnie łączy się z pojęciem pokoju. Upadek muru był spowodowany pragnieniem wolności, jednak dziś nie możemy stwierdzić, że sytuacja Europy charakteryzuje się wolnością i pokojem. Niestety, przemoc jest potencjalnie zawsze obecna. Benedykt mówi: „Wolność jest wielkim dobrem. Jednak świat wolności okazał się w dużej mierze zdezorientowany, a wolność jest przez wielu błędnie utożsamiana z wolnością ku przemocy. Niezgoda przybiera nowe, zastraszające oblicza i walka o pokój musi w nowy sposób pobudzać wszystkich nas". ${ }^{27}$

Pokój w rozumieniu Kościoła nie ogranicza się do stwierdzenia, że jest to brak wojny, lecz uznaje ten stan ze element niezbędny do budowania pozytywnych stosunków między państwami oraz struktur społecznych w państwie, element przestrzegania praw człowieka, likwidacji sytuacji wywołującej konflikty. ${ }^{28}$ Greckie słowo ejrene, które w pierwotnym znaczeniu oznacza brak konfliktu, w Nowym Testamencie rozumiane jest jako pokój urzeczywistniający się zarówno w stanie ducha, jak i we współżyciu między ludźmi. Pokój nie może być traktowany jako program polityczny, gdyż jego źródłem jest Bóg. ${ }^{29}$ Chrześcijanie to ludzie pokoju, który został im dany i który oni mają obowiązek nieść innym ludziom. Troska o pokój jest wpisana w społeczeństwo, które powinno o ten wielki dar, jakim jest pokój, prosić. Dlatego też Kościół propaguje modlitwę o pokój, „która oznacza przecież

26 Tamże, s. 169.

27 „Zagrożeniem dla pokoju jest antyreligia”. Przemówienie Benedykta XVI w Asyżu, Pedagogia Ojcostwa: katolicki przegląd społeczno-pedagogiczny 2/ 2012, s. 20.

28 Zob. S. F e 1, Pokój i jego zagrożenia, Zeszyty Społeczne KIK 10/2002, s. 109.

29 Zob. J.J. P awli k, Światopoglądowe uwarunkowania koncepcji pokoju, s. 82 . 
nic innego, jak otwarcie, słuchanie, dialog i, ostatecznie, zjednoczenie z Bogiem - pierwotnym źródłem prawdziwego pokoju". ${ }^{30}$ Modlitwa jest przede wszystkim prośbą o uwolnienie od strachu przed wojną i od zniewolenia przez wojnę, ale dotyczy ona również jej ofiar i sprawców. „Piąte przykazanie zakazuje dobrowolnego niszczenia życia ludzkiego. Z powodu zła i niesprawiedliwości, jakie pociąga za sobą wojna, Kościół usilnie wzywa wszystkich do modlitwy i działania, by dobroć Boża uwolniła nas od odwiecznego zniewolenia przez wojnę". ${ }^{31}$ Modlitwa o pokój dotyczy wszystkich religii, dlatego też należy dążyć do wspólnej modlitwy, która jest wyrazem solidarności. Należy odrzucić nienawiść i chęć zemsty. Modlitwa jest wyrazem prawidłowej relacji z Bogiem i z drugim człowiekiem, daje nam możliwość dokładniejszego poznawania Ewangelii, dlatego też dzięki niej jesteśmy w stanie budować pokój. „Modlitwa jest wyrazem i jednocześnie szkołą postaw. W niej człowiek, który wierzy w istnienie prawdy, poszukuje prawdy i ją odnajduje". ${ }^{32}$

Ważnym aspektem w budowaniu pokoju jest pojednanie Żydów i chrześcijan, gdyż ,powinni stać się siłą pokoju dla tego świata. Dzięki ich świadectwu o Bogu Jedynym, który pragnie być czczony nie inaczej jak tylko w jedności miłości Boga i bliźniego, powinni otworzyć oni Bogu bramy tego świata, aby spełniła się Jego wola i aby na ziemi mogło być «jak w niebie», zgodnie z prośbą: «przyjdź królestwo Twoje»" ${ }^{33}$

Kardynał Ratzinger jako papież Benedykt XVI każdego roku swojego pontyfikatu wygłaszał orędzie w Światowym Dniu Pokoju, który w 1968 r. z woli papieża Pawła VI został ustanowiony na 1 stycznia. ${ }^{34}$ W 2006 r. nosiło ono tytuł Pokój w prawdzie. Benedykt XVI mówi, że pokój jest darem Boga i jednocześnie pragnieniem każdej osoby bez względu na jej tożsamość kulturową. Zwrócił w nim uwagę na to, że

30 T. Z a d y k o w i c z, Modlitwa droga pokoju, w: J. N a gó r n y, M. P ok r y w k a, Wojna - sprawiedliwa? Przesłanie moralne Kościoła, Lublin 2003, s. 167.

31 Katechizm Kościoła Katolickiego, Poznań 2002, nr 2307.

32 T. Z a d y k o w i c z, Modlitwa droga pokoju, s. 179.

33 J. R a t z i n g e r, Wielość religii i jedno Przymierze, Poznań 2004, s. 37.

34 T. Pła s k i, Sprawiedliwa wojna i pokój w nauczaniu Kościoła katolickiego, Studia Warmińskie t. 41-42/2004-2005, s. 349. 
katolik ma obowiązek dawać świadectwo o Bogu i głosić „Ewangelię pokoju”. „Prawda o pokoju wymaga, aby wszyscy - zarówno rządy, które w sposób zdeklarowany czy utajniony posiadają broń nuklearną, jak też te, które mają zamiar ją zdobyć - razem odwrócili bieg spraw, dokonując jasnych i trwałych wyborów, zmierzając zgodnie ku postępującemu i wspólnemu rozbrojeniu nuklearnemu. Zaoszczędzone w ten sposób środki mogą być wykorzystane w programach rozwoju, obejmujących wszystkich mieszkańców, a w pierwszym rzędzie najbiedniejszych". ${ }^{35}$ Pokój pochodzi od Boga, jest nam dany za pomocą miłości i sprawiedliwości. Prawdziwy pokój to prawda, która może być niszczona przez kłamstwo i grzech.

Fundamentem każdego społeczeństwa jest rodzina, która jest bardzo ważna w tworzeniu pokoju i poczucia bezpieczeństwa. Wzajemne doświadczanie miłości, dawanie życia, dbanie o nie, uczenie postawy wzajemnego poszanowania godności ludzkiej, miłość ojczyzny to podstawowe cele rodziny, która właśnie w ten sposób wychowuje do pokoju ${ }^{36}$ Rodzina wspólnota pokoju to orędzie papieża Benedykta XVI z 2008 r., w którym podkreśla, że zdrowa rodzina to taka, która daje miłość i poczucie sprawiedliwości, przez co staje się pierwszą wychowawczynią życia i główną szkołą pokoju.$^{37}$ Kontynuacją tej myśli jest orędzie z 2012 r. Wychowanie młodzieży do sprawiedliwości i pokoju, w którym papież, nawiązując do roli rodziny jako formacji odpowiedzialnej za różne dziedziny życia społecznego, religijnego, politycznego, gospodarczego i kulturalnego, mówi o wpajaniu młodym ludziom pozytywnych wartości życia. Ważne jest wychowanie młodzieży w prawie do wolności, do szanowania jej i umiejętnego z niej korzystania. ${ }^{38}$ Wcześniejsze orędzie z 2011 r.

35 http://www.opoka.org.pl/biblioteka/W/WP/benedykt xvi/przemowienia/ pokoj2006-or_08122005.html, (dostęp: 21 III 2016).

36 Zob. M. P o k r y w k a, Rola rodziny w wychowaniu do pokoju, w: N a g ó r n y, M. P o k r y w k a, Wojna-sprawiedliwa? Przesłanie moralne Kościoła, s. 183-199.

37 Zob. http://www.opoka.org.pl/biblioteka/W/WP/benedykt_xvi/przemowienia/ pokoj2008_11122007.html (dostęp: 21 III 2016).

38 Zob. https://w2.vatican.va/content/benedict-xvi/pl/messages/peace/documents/ hf_ben-xvi_mes_20111208_xlv-world-day-peace.html\#_ftnl (dostęp: 10 II 2016). 
porusza kwestię wolności religijnej, która stanowi źródło wolności moralnej. Człowiek ma prawo do wyznawania i wyrażania własnej religii. Wzajemna akceptacja wśród różnych wyznań jest podstawą do budowania pokoju w świecie. „Wolność religijna jest autentyczną bronią pokoju, a jej misja jest historyczna i profetyczna. Ona bowiem dowartościowuje i wykorzystuje najgłębsze zalety i możliwości osoby ludzkiej, zdolne zmienić świat i uczynić go lepszym. Pozwala żywić nadzieję na przyszłość sprawiedliwą i pokojową, również w obliczu wielkich niesprawiedliwości oraz nędzy materialnej i moralnej”. ${ }^{9}$ Papież zwraca uwagę na ubóstwo, które w dobie globalizacji rozwija się w szybkim tempie i - jak zaznacza - nie jest wynikiem rozwoju demograficznego, gdyż ludność sama w sobie jest bogactwem, a nie jego brakiem. Wszelkiego rodzaju pandemie, brak dostępu do leków, osłabienie bezpieczeństwa rodzin, kryzys żywnościowy są podstawą ubóstwa, a tam, gdzie nie ma poczucia sprawiedliwości, gdzie brakuje kodeksu etycznego, dochodzi do aktów przemocy i terroru. ${ }^{40}$

By pokój mógł istnieć na świecie, musi najpierw zapanować w sercu człowieka, musi być wzajemny szacunek między narodami. Niestety, nie jest on dany raz na zawsze, ale dostaliśmy możność tworzenia go jako wspólnego dobra, zaczynając od swoich małych wspólnot i społeczności. Joseph Ratzinger jako kardynał i później papież Benedykt XVI proponuje wybranie wspólnej drogi z Kościołem katolickim, by w dzisiejszych czasach budować pokój, opierając się na chrześcijańskiej tożsamości Europy.

Adriana POGODA-KOLODZIEJAK

39 Wolność religijna droga do pokoju, Orędzie na Światowy Dzień Pokoju 2011 roku, http://www.opoka.org.pl/biblioteka/W/WP/benedykt_xvi/przemowienia/ pokoj2011-or_08122010.html (dostęp: 10 II 2016).

40 Zob. Zwalczanie ubóstwa drogą do pokoju, Orędzie Ojca Świętego Benedykta XVI na Światowy Dzień Pokoju 1 stycznia 2009 roku, http://w2.vatican.va/content/ benedict-xvi/pl/messages/peace/documents/hf_ben-xvi_mes_20081208_xlii-world-day-peace.html (dostęp: 14 II 2016). 
Słowa kluczowe: Joseph Ratzinger, Europa, kryzys, pokój, Bóg, Kościół

Keywords: Joseph Ratzinger, Europe, crisis, peace, God, the Church

\section{The role of the Church in the European peace crisis according to Joseph Ratzinger \\ Summary}

Is modern Europe just a mental idea? Is it, as the moral force after World War II, the power of reconciling nations, and of establishing and creating peace? In the understanding of the Church, peace does not reduce itself to the mere absence of war, but such a state is recognized as an essential element in forming positive relations between countries and creating social structures within them. Cardinal Joseph Ratzinger assigns to Christians certain tasks thanks to which world peace can be preserved. The Church ought to instil the habit of defending it by exhibiting values which stand up to war and violence, the most important of which is love towards fellow human beings. Man has to sensitize himself to God in order to feel the power of conscience, which will allow him to create good law in society. 